\title{
PROFESSIONAL MASTERY OF ACADEMICS IN HIGHER EDUCATION: THE CASE OF LATVIA
}

\author{
Dace Medne \\ J. Vītols Latvian Academy of Music, Latvia \\ Nora Jansone Ratinika \\ Rīga Stradinš̌ University, Latvia
}

\begin{abstract}
The whole higher education (HE) teaching and learning environment nowadays is formed by similar phenomena: greater, more ambitious and diverse student structure, high quality demands, rapidly changing technological opportunities, higher hopes from government, students and employers that the graduates will be prepared for quickly changing workplaces. Changes and uncertainty in the world are unceasing topics of discussion and research in any industry. Preparing students to live in today's uncertain world is an important task for universities. In the context of a suitable study process development, at the moment study programmes and study courses in HE institutions in Latvia are being reorganised, new demands are being defined for academic staff, extensive evaluation of study process and involved participants is being carried out, including one of the common practices in HE institutions - student surveys. The obtained results are being used not only in quality assurance for quality control but also to establish the necessary improvements and continuous development of studies. Yet, more and more frequently employers state that graduates are not sufficiently prepared for the changing and uncertain world and professional life. Why? As the 'world of work' has also advanced, the changes in HE institutions are not always being implemented according to the dynamic demands of the industries. The implementation of changes brings about not only a shift in organisation of HE institution performance but also changes in perception and comprehension of students and academic staff. With the purpose of study process supervision, the opinion of students is identified more frequently than the opinion of academic staff. Therefore, a question about how academic staff of HE institutions implement their professional activity that forms the framework of their professional mastery, becomes topical, because the professional mastery of HE academic staff is a prerequisite for the processes of development of student professional mastery. The way how academic staff of HE institution see themselves as people, as lecturers, is an important aspect of how they implement their professional mastery (Ashwin et al., 2015). This demand formed the research question: what creates the professional mastery framework of a HE lecturer who prepares students for a situation of uncertainty and changes. In order to answer the research question, scientific literature was analysed, a binding framework and reasoned professional academic staff framework
\end{abstract}


established, the explanations of criteria for professional mastery of the academic staff of HE in day-to-day professional activity were identified.

Keywords. Higher Education, Professional Mastery, Professional Activity.

\section{Introduction}

The idea of sustainable development is the primary goal of $21^{\text {st-century }}$ education. Education for sustainable development promotes people's responsibility in everyday life: self-realising in line with the social, cultural, economic and natural environments. Therefore, the aim of education for sustainable development is a person who lives not only in accordance with nature and other cultures but also is able to realise himself fully in the economy and in society as a whole, ensuring the long-term and thoughtful use of resources. Such a person understands local problems and can view them in a global context, understands other cultures with respect. Furthermore, this person is also capable of building healthy relationships of different levels (personal, professional), thus creating a sustainable society and promoting its economic growth. The Sustainable Development Strategy of Latvia until 2030 emphasizes that the quality of education, its availability and content are major challenges for the development of human capital. Higher education is not only a process of acquiring specific competencies and qualifications but also a process of developing human talents, emotional intelligence and personality. The National Development Plan of Latvia for 2014-2020, therefore, identifies "Economic growth" as one of its priorities and "Developed research, innovation and higher education" as one of the actions to achieve it. In order to implement the National Development Plan of Latvia, professional HE institution lecturers, whose professional mastery is one of the prerequisites for the qualitative implementation of the study process and the development of a healthy study environment, are required. An equally important context of the problem to be analysed is that the whole HE teaching and learning environment nowadays is formed by similar phenomena: greater, more ambitious and diverse student structure, high quality demands, rapidly changing technological opportunities, higher hopes from government, students and employers that the graduates will be prepared for quickly changing workplaces. Changes and uncertainty in the world are unceasing topics of discussion and research in any industry. Preparing students to live in today's uncertain world is an important task for universities. Therefore, a question about how academic staff of HE institutions implement their professional activity that forms the framework of their professional mastery, becomes topical, because the professional mastery of HE academic staff is a prerequisite for the processes of 
development of student professional mastery. The way how academic staff of HE institutions see themselves as people, as lecturers, is an important aspect of how they implement their professional mastery (Ashwin et al., 2015). Nowadays, the HE lecturer not only prepares the new specialists for the needs of the national economy, but also introduces them to further lifelong learning and research activities. Therefore, the content of the social role of lecturers is changing. They become supporters, partners, inspirers and guides in the selection and acquisition of knowledge, in the learning process. Nowadays, the HE lecturers also keep learning, direct their own and students' knowledge, act as entrepreneurs. Scientific knowledge is used in the study process in the development of teaching materials and tools; students engage in scientific research, thereby building and developing their research and professional competencies necessary for the sustainable development of society. The context of HE reforms helps to identify the problem to be analysed in the study: the importance of the professional mastery of a lecturer in building healthy communication in the study process. The subject of the research is the analysis of the professional mastery of lecturers in the provision of sustainable education.

The described situation reveals the research problem on which the research questions are based:

1) what criteria form the framework of the professional mastery of the academic staff?

2) how are the components of the framework of the professional mastery of HE lecturers outlined in the lecturers' interviews?

\section{The Context}

A professional is a person who has graduated from an accredited initial training program, including specialized knowledge in accordance with a professional standard, and who is approved as a registered practitioner with the right to express an autonomous professional judgment (Hooley, 2007). Professional mastery is linked to the concept of "a profession and a professional" (Munoz Palm, 2008). The framework of professional mastery consists of (1) competence in the field of specialization, (2) moral integrity (values) and (3) didactic competence (Carr, 2000; Shon, 2006). This framework acts as a foundation for all professionals and is useful for achieving the objectives of professional communities. This content of the framework of professional mastery is therefore also relevant to the professional mastery of the HE lecturer. Law (the Law on Institutions of Higher Education of the Republic of Latvia, LV § Section 27, 1995) states that the academic staff of an institution of higher education shall conduct scientific research and participate in the educating of students. 
Professional mastery also includes focusing on pedagogical work, becoming a competent professional in one's field, respecting professional ethics, maintaining a healthy emotional climate in higher education institutions and the professional identity of university lecturers (Commonwealth Secretariat, 2012). In the context of professional mastery, Archer (2000) emphasizes the importance of a sense of belonging; a sense of belonging is exercised through "internal conversation", through an activity she calls "reflection" It can, therefore, be concluded that the professional mastery framework of HE lecturers consists of the following dimensions: pedagogical (didactic), occupational (the sector in which the lecturer is teaching) and research-related. Scientists agree that professional mastery is closely related to professional identity (Marcelo, 2009). Through professional identity, HE institution lecturers perceive themselves and form their own professional mastery on the basis of self-perception. Professional identity is the function of $\mathrm{HE}$ institution lecturers to define themselves and others (Marcelo, 2009). Continuous professional development is a necessary condition for the professional mastery of HE institution lecturers. Similarly, the available literature reaffirms the importance of professional identity in strengthening quality in the education sector. The quality of higher education refers to effective teaching and learning resulting from suitable resources, including the professional mastery of university teachers (Okebuka, Shabani, 2007). Through the analysis of the scientific literature, it can be concluded that there is no common view on what constitutes the professional framework of a HE institution lecturer, therefore, an empirical study was carried out in order to identify the components of professional mastery of a HE institution lecturer in the context of Latvia.

\section{Methodology and Process}

The study was carried out in a qualitative approach, using the content analysis of interviews with 20 lecturers from different Latvian higher education institutions, which allows to analytically and descriptively compare the thematic diversity expressed in the narratives of interviews with the views identified in pedagogical literature and other secondary sources. For linguistic analysis of the narrative content of HE institution lecturers, primary content association-raising basic factors - the personality characteristics of HE institution lecturers - were selected. In the secondary selection, the names of the respective actors and their activities with identical and close meaning were identified - forms of a word in various tenses or conjugations, singular and plural forms, diminutives, which characterize the social roles and functions of the basic actors. The social roles and functions of the basic actors were analysed according to the dimensions 
identified in the theoretical findings: pedagogical, occupational (the sector in which the lecturer is teaching) and research-related.

According to the amount of data to be processed, the linguistic analysis of HE institution lecturer interviews was carried out during the first level of empirical analysis using the QSR NVivo 12 Quality data processing programme; the identified content units were analysed manually. The choice of a computer program was determined by functional advantages: (1) it offers to automate the analysis of the original primary data array and manually adjust it to the content at later levels of analysis. It makes it easy to collect and systematize qualitative data; to identify frequently used words, the context of their use and meanings by carrying out simple concessional analysis; (2) it provides an opportunity to automatically filter large-scale data accurately in a short time across different cross-sections and contexts, thereby significantly accelerating their analysis and increasing the level of its objectivity. (3) A computer program consecutively retains historical commands, allowing the researcher to manage the course of coding and analysis in a meaningful way (Bryman, 2016; Bazeley, Jackson, 2013).

Data processing and analysis were implemented on several levels: (1) the content units of interviews were imported into the NVivo file, technically edited and sequentially coded, with the frequency initially set at 3,000-words; then, based on their weighted rate of frequency, 184 identified and selected, and of those, 15 basic keywords (codes) which characterise the professional mastery of a HE institution lecturer; (2) hierarchical coding-grouping was implemented to identify mutually thematically related keywords and groups, their frequency of use and contextual meanings, that reveal the essence of the research focus "the professional mastery of a HE institution lecturer"; (3) based on the code structure created through content analysis, the framework of the professional mastery of a HE institution lecturer was created, designed for planning, promoting and supporting personal, professional and career development goals in higher education.

\section{Results}

Gender distribution of respondents: female $(n=15)$ and male $(n=5)$, their age varies from 30 to 56 years. The most frequently used words in the interviews are shown in Table 3.1; they were analysed by frequency, namely, numerical values: the frequency of each code (number showing how often it is referred to in the text) and the weighted percentage of the word indicating the frequency of the code in the total text volume. The interview codes used in the interviews were analysed interrelatedly by using content analysis and context analysis. 
Table 1. The Most Frequently Identified Words in Interviews

\begin{tabular}{|c|c|c|}
\hline Word & Count & Weighted Percentage (\%) \\
\hline self-reflection & 40 & 14.63 \\
\hline healthy self-esteem & 37 & 13.17 \\
\hline health and safety & 35 & 12.12 \\
\hline perseverance & 30 & 11.63 \\
\hline learning skills & 30 & 11.63 \\
\hline discussions & 27 & 11.36 \\
\hline responsibility & 25 & 11.08 \\
\hline enthusiasm & 24 & 8.66 \\
\hline humour & 24 & 8.66 \\
\hline assessment skills & 19 & 8.38 \\
\hline equality & 18 & 8.24 \\
\hline information literacy & 17 & 7.96 \\
\hline ability to regulate emotions & 16 & 7.78 \\
\hline motives for choosing a profession & 15 & 7.77 \\
\hline attitudes towards innovation & 15 & 7.77 \\
\hline prioritization & 28 & 7.59 \\
\hline analysis & 28 & 7.59 \\
\hline creativity & 28 & 7.59 \\
\hline to feel in harmony & 27 & 7.58 \\
\hline belief in oneself & 25 & 7.00 \\
\hline to feel interested & 23 & 6.91 \\
\hline return & 19 & 6.86 \\
\hline time management & 19 & 6.86 \\
\hline satisfaction & 18 & 6.57 \\
\hline respect & 17 & 6.47 \\
\hline reaction to change & 16 & 5.78 \\
\hline knowledge & 16 & 5.78 \\
\hline positive self-image & 15 & 5.65 \\
\hline continuous professional development & 14 & 5.42 \\
\hline self-organization & 14 & 5.42 \\
\hline preparation & 14 & 5.42 \\
\hline work-life balance & 14 & 5.42 \\
\hline resources & 12 & 4.26 \\
\hline critical thinking & 11 & 3.97 \\
\hline infrastructure & 9 & 3.83 \\
\hline cooperation & 10 & 3.61 \\
\hline problem-solving skills & 10 & 3.61 \\
\hline language skills & 10 & 3.61 \\
\hline
\end{tabular}


Through analysis of the results obtained (Table 1), it can be concluded that the most frequently used words in the interviews of the HE institution lecturers reflect that, in the content of their professional mastery, personality traits of the lecturers, as well as functions (activities) and skills are included. The most commonly used words illustrate the professional mastery of HE institution lecturers as a self-reflective, dynamic and goaloriented part of their personalities. In order to determine the framework of professional mastery of university lecturers, in the program actions were taken to identify the most frequent interrelations between commonly used words, and a scheme was created that reflects their interconnectedness in thematic blocks (their order based on subordination). Data analysis points to three blocks of word interrelation: personal efficiency, knowledge, and emotional satisfaction, where the order of words indicates the complexity of the relationship between them. For the sake of visualisation, the programme scheme has been manually narrowed to three interrelation blocks (Table 2).

Table 2. Breakdown of the Most Frequent Interrelations Between Words. Personal Effectiveness

\begin{tabular}{|l|l|l|}
\hline \multicolumn{1}{|c|}{ Word } & \multicolumn{1}{|c|}{ Association } & \multicolumn{1}{c|}{ Sub-block } \\
\hline personal \\
effectiveness & $\begin{array}{l}\text { prioritization } \\
\text { humour } \\
\text { preparation } \\
\text { perseverance } \\
\text { time management } \\
\text { enthusiasm } \\
\text { motives for choosing a profession }\end{array}$ & \\
\cline { 2 - 4 } & $\begin{array}{l}\text { reaction to change } \\
\text { self-organization } \\
\text { self-reflection } \\
\text { responsibility }\end{array}$ & work-life balance \\
\cline { 2 - 4 } & $\begin{array}{l}\text { belief in oneself } \\
\text { problem-solving skills } \\
\text { respect } \\
\text { ability to regulate emotions } \\
\text { healthy self-esteem }\end{array}$ & positive self-image \\
\hline
\end{tabular}

The first word interrelation block is based on the word personal effectiveness (Table 3), which is composed of three sub-blocks: return, work-life balance and positive self-image. The word return is related to the words: motives for choosing a profession, enthusiasm, prioritization, 
humour, preparation, perseverance and time management skill. The combination of words work-life balance is related to words: reaction to change, self-organization, self-reflection and responsibility. The words ability to regulate emotions, belief in oneself, problem-solving skills, respect and healthy self-esteem are associated with the word combination positive self-image.

Table 3. Breakdown of the Most Frequent Interrelations Between Words. Knowledge

\begin{tabular}{|l|l|l|}
\hline \multicolumn{1}{|c|}{ Word } & \multicolumn{1}{|c|}{ Association } & \multicolumn{1}{c|}{ Sub-block } \\
\hline knowledge & $\begin{array}{l}\text { analysis } \\
\text { learning skills } \\
\text { critical thinking }\end{array}$ & language skills \\
\cline { 2 - 3 } & $\begin{array}{l}\text { problem-solving skills } \\
\text { creativity } \\
\text { attitude to innovation } \\
\text { assessment skills }\end{array}$ & information literacy \\
\hline
\end{tabular}

The word block of words is composed of the word knowledge (Table 4), which consists of two sub-blocks: language skills and information literacy. Composition of the words language skills is related to the words: analysis, earning skills, critical thinking. Composition of the words information literacy involves words: problem-solving skills, creativity, attitude to innovation and assessment skills.

Table 4. Breakdown of the Most Frequent Interrelations Between Words. Emotional Satisfaction

\begin{tabular}{|l|l|l|}
\hline \multicolumn{1}{|c|}{ Word } & \multicolumn{1}{|c|}{ Association } & \multicolumn{1}{|c|}{ Sub-block } \\
\cline { 3 - 3 } satisfaction & $\begin{array}{l}\text { resources } \\
\text { health and safety } \\
\text { responsibility }\end{array}$ & infrastructure \\
\cline { 2 - 3 } & $\begin{array}{l}\text { continuous professional development } \\
\text { discussions } \\
\text { respect } \\
\text { to feel interested } \\
\text { to feel in harmony } \\
\text { equality }\end{array}$ & \\
& cooperation \\
& ability to regulate emotions & \\
\hline
\end{tabular}


The third word block consists of the word satisfaction (Table 4), which consists of two sub-blocks: infrastructure and cooperation. The word infrastructure is associated with the words: resources, health and safety, responsibility. Word cooperation is related to words: continuous professional development, discussions, respect, to feel interested, to feel in harmony, equality and ability to regulate emotions.

\section{Discussion}

When analysing the results of the study, the research questions of the study can be answered: all the dimensions of professional mastery of the higher education institution lecturers identified in theories are outlined in the interview content topics. The results suggest that HE institution lecturers do not implement their professional mastery based on the model they have witnessed, observed and acknowledged as appropriate, but consciously develop their professional mastery as part of their personality. It can be concluded that the most frequently used words in HE lecturer interviews reflect the framework of professional mastery, and it consists of personality traits as well as functions (activities) and skills. Thus, a framework of professional craftsmanship can be created with facets of personal efficiency, knowledge and satisfaction. Satisfaction encompasses both infrastructure and cooperation aspects, so it can be concluded that this block is at the core of the learning process shift, from the subject's position, into an open communicative space: the circulation of ideas, approbation and joint evaluation. Knowledge is related to the lecturer's skills to acquire the necessary information of varied content and nature, to navigate through it and to use the information in such a way that the added value of knowledge is created. The obtained results confirm nowadays that acquisition of new knowledge is closely related to information management, promoting the necessity of lifelong learning. The self-efficiency block, on the other hand, includes how the HE institution lecturers perceive themselves, feel and behave, what attitudes towards the new they develop. The self-efficiency block includes indicators that characterize personality traits and skills to manage different situations. It can be concluded that the idea of learning through teaching is the basis of the professional mastery framework of the lecturers.

This study can be considered as a pilot study for further research, as the study had a number of limitations: a small number of respondents and interviews were conducted only in the HE institutions located in the capital. In order to gain a deeper understanding of the professional mastery of HE institution lecturers, the study could be continued by exploring the in-depth content of each facet as well as by continuing to 
increase their number. Therefore, in assessing further aspects of the HE institution lecturer's professional mastery discourse study, they could be subject to the conclusion of historian Victoria Harris, that, in the future, succession should be enriched, not by studying discourses, because they reveal categories, and the categories are flowing and relative, but through focusing research on specific experiences (Harris, 2010).

\section{References}

Ashwin, P., Boud, D., Coate, K., Hallett, F., Keane, E., Krause, K. L., Leibowitz, B., MacLaren, I., McArthur, J., McCune, V., Tooher, M. (2015). Reflective Teaching in Higher Education.UK: Bloomsbury Academic.

Law on Institutions of Higher Education of the Republic of Latvia (Latvijas Republikas Augstskolu likums). Retrieved from https://likumi.lv/doc.php?id $=37967$.

Bazeley, P., Jackson, K. (2013). Qualitative data analysis with NVivo. London: SAGE Publications.

Bohley P. (2016). Identität. Wie sie entsteht und warum der Mensch sie braucht [How it originates and why man needs it]. Marburg: Tectum Verlag.

Bryman, A. (2016). Social Research Methods. UK: Oxford University Press.

Carr D. (2000). Professionalism and Ethics in Teaching. London and New York: Routledge.

Commonwealth Secretariat (2012). The role and future of the commonwealth. Retrieved from https://publications.parliament.uk/pa/cm201012/cmselect/cmfaff/writev/ commonwealth/com17.htm.

Harris, V. (2010). Sex on the margins: new directions in the historiography of sexuality and gender. The Historical Journal, 53 (4). 1085-1104.

Hooley, N. (2007). Establishing Professional Identity: Narrative as Curriculum for PreService Teacher Education. Australian Journal of Teacher Education, 32(1). Retrieved from http://dx.doi.org/10.14221/ajte.2007v32n1.4.

The National Development Plan of Latvia for 2014-2020 (Latvijas Republikas Latvijas Nacionālais attīstības plāns 2014.-2020. gadam). Retrieved from https://likumi.lv/doc. php?id $=253919$.

Marcelo, C. (2009) Professional Development of Teachers: past and future. Sisifo. Educational Sciences Journal, 8, 5-20.

Munoz Palm, R. C. (2008). Professional Identify of the Occupational Therapist. TOG (A Coruna) (Internet Journal), 5(2), 110-125. Retrieved from http://www.revistatog. com/ mono/num2/palm_ing.pdf.

Okebukola, P., Shabani, J. (2007). Quality assurance and accreditation in higher education in Sub-Sarahan Africa. In Tres, J., Sanyal, B. C. (Eds.), Higher Education in the World 2007: Accreditation for Quality Assurance: What is at Stake?, 188-200. New York: Palgrave Macmillan.

Shon Ch.K. (2006). Teacher Professionalism. Faculty Publications and Presentations. 46. Retrieved from http:// digitalcommons.liberty.edu/cgi/viewcontent.cgi?article $=1053 \&$ context $=$ educ_fac_pubs. 